\title{
The trophic biology of the holothurian Molpadia musculus: implications for organic matter cycling and ecosystem functioning in a deep submarine canyon
}

\author{
T. Amaro ${ }^{1,3}$, S. Bianchelli ${ }^{2}$, D. S. M. Billett ${ }^{3}$, M. R. Cunha ${ }^{1}$, A. Pusceddu ${ }^{2}$, and R. Danovaro ${ }^{2}$ \\ ${ }^{1}$ CESAM e Departamento de Biologia, Universidade de Aveiro, Campus Universitário de Santiago, 3810-193 Aveiro, \\ Portugal \\ ${ }^{2}$ Dipartimento di Scienze del Mare,Università Politecnica delle Marche, Via Brecce Bianche, 60131 Ancona, Italy \\ ${ }^{3}$ National Oceanography Centre, Southampton University of Southampton, Waterfront Campus, European Way Southampton \\ SO14 3ZH, UK
}

Received: 9 April 2010 - Published in Biogeosciences Discuss.: 28 April 2010

Revised: 20 July 2010 - Accepted: 3 August 2010 - Published: 16 August 2010

\begin{abstract}
Megafaunal organisms play a key role in ecosystem functioning in the deep-sea through bioturbation, bioirrigation and organic matter cycling. At $3500 \mathrm{~m}$ water depth in the Nazaré Canyon, NE Atlantic, very high abundances of the infaunal holothurian Molpadia musculus were observed. To quantify the role of M. musculus in sediment cycling, sediment samples and holothurians were collected using an ROV and in situ experiments were conducted with incubation chambers. The biochemical composition of the sediment (in terms of proteins, carbohydrates and lipids), the holothurians' gut contents and holothurians' faecal material were analysed. In the sediments, proteins were the dominant organic compound, followed by carbohydrates and lipids. In the holothurian's gut contents, protein concentrations were higher than the other compounds, decreasing significantly as the material passed through the digestive tract. Approximately $33 \pm 1 \%$ of the proteins were digested by the time sediment reached the mid gut, with a total digestion rate equal to $67 \pm 1 \%$. Carbohydrates and lipids were ingested in smaller amounts and digested with lower efficiencies $(23 \pm 11 \%$ and $50 \pm 11 \%$, respectively). As a result, the biopolymeric $\mathrm{C}$ digestion rate was on average $62 \pm 3 \%$. We estimated that the population of M. musculus could remove approximately $0.49 \pm 0.13 \mathrm{~g}$ biopolymeric $\mathrm{C}$ and $0.13 \pm 0.03 \mathrm{~g} \mathrm{~N} \mathrm{~m}^{-2} \mathrm{~d}^{-1}$ from the sediments. These results suggest that M. musculus plays a key role in the benthic tropho-dynamics and biogeochemical processes in the Nazaré Canyon.
\end{abstract}

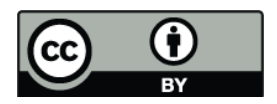

Correspondence to: T. Amaro (amaro@ua.pt)

\section{Introduction}

The deep sea is the largest ecosystem on Earth, covering about $60 \%$ of the globe's surface. Deep-sea ecosystems provide the largest reservoirs of biomass and non-renewable resources (Gage and Tyler, 1991), which are linked to their biodiversity (Danovaro et al., 2008b). They act as the ultimate sink for organic material derived from the upper ocean's primary production and are essential in the biogeochemical cycling of organic matter (OM) on a global scale (Dell'Anno and Danovaro, 2005; Danovaro et al., 2008a).

Deep-sea submarine canyons host hotspots of OM and biomass (Gage et al., 1995; Vetter and Dayton, 1998; Duineveld et al., 2001; Bianchelli et al., 2008; Ingels et al., 2009; Tyler et al., 2009; de Leo et al., 2010; Pusceddu et al., 2010; Vetter et al., 2010). Within canyons, biodiversity is high as a result of their topographic complexity and spatio-temporal variability (Bianchelli et al., 2008; Ingels et al., 2009; Tyler et al., 2009; Vetter et al., 2010). The topographic complexity of canyons makes them difficult ecosystems to investigate. As a result, knowledge of their ecological functioning (e.g., community respiration, productivity, nutrient cycling, OM supply and remineralisation rates) are largely unknown.

The Nazaré Canyon is a major conduit of organic matter and sediment on the Portuguese margin, and one of the most spectacular topographic features of the NE Atlantic margin (de Stigter et al., 2007; Arzola et al., 2008; Masson et al., 2010). Large concentrations of organic $C$ and biopolymeric $\mathrm{C}$ (BPC) have been observed within the middle section of the Nazaré Canyon, suggesting this canyon may act as a sink for OM burial (Schmidt et al., 2001; de Stigter et al.,

Published by Copernicus Publications on behalf of the European Geosciences Union. 
2007; Masson et al., 2010; Pusceddu et al., 2010). Sediments and $\mathrm{OM}$ are transported from the continental shelf down the canyon and into the deep sea (de Stigter et al., 2007; Oliveira et al., 2007; de Leo et al., 2010; Vetter et al., 2010). Enrichment of OM in canyon sediments leads to enhanced benthic abundance and biomass (Rowe et al., 1982; Soetaert et al., 1991; Vetter and Dayton, 1998, 1999; Palanques et al., 2005; Bianchelli et al., 2008), and increased metabolic activities (Duineveld et al., 2001; Accornero et al., 2003).

In the central part of the Nazare Canyon ( $3500 \mathrm{~m}$ depth) the deep-sea burrowing sea cucumber, Molpadia musculus (Riso, 1826), occurs in consistently high abundances, which is unusual for a deep-sea burrowing species at this depth (Amaro et al., 2009). The reasons for such high abundances remain unknown. The particulate organic carbon (POC, e.g. the food supply) that arrives on the seabed is an important factor controlling the abundance and composition of macrofauna and megafauna (Sibuet, 1985; Ruhl, 2007; Smith et al., 2008; Ruhl et al., 2008; de Leo et al., 2010). Ruhl and Smith (2004) found significant correlations between food supply and megafaunal abundance, in particular holothurians, over a 14-year time series at an abyssal site in the NE Pacific Ocean. They found that the abundance of some species increase in abundance during periods of high food availability, whereas the abundance of others increase with periods of low food supply. Similar correlations have also been reported in the Porcupine Abyssal Plain (PAP) in the northeast Atlantic (Billett et al., 2001). Food sources for benthic organisms may include organic detritus (including seagrass/algae debris and dead or decaying animals), microorganisms (prokaryotes, diatoms, protozoans) and faecal pellets of other animals (Massin, 1982; Moriarity, 1982; Jumars, 1993; Roberts et al., 2001). The relative proportions of these potential food items and their biochemical composition determine the nutritional value of the ingested material, which, in turn, regulates the potential utilization rates by benthic fauna (Fabiano et al., 1999) and, in particular, by depositfeeding holothurians (Purinton et al., 2008). A proportion of the material ingested by benthic heterotrophs is still fresh (i.e., recently deposited detritus from the surface ocean), but some is already degraded either by planktonic organisms during the particles descent to the sea bottom (Turley and Mackie, 1995; Wakeham et al., 1997) or by other benthic metazoans and/or prokaryotes (Smith et al., 1993; Levin et al., 1997; Miller et al., 2000). The largest fraction of OM in deep-sea sediments is composed of refractory compounds and becomes available to higher benthic organisms only after ageing and microbial breakdown (Danovaro et al., 1993; Pusceddu et al., 2009). Although there have been several investigations of the nutrition of deposit-feeding holothurians (Deming and Colwell, 1982; Sibuet et al., 1982; Billett et al., 1988; Roberts et al., 1991; Roberts et al., 2000; Ginger et al., 2001; Witbaard et al., 2001; Hudson et al., 2005), the debate concerning the biological and chemical composition of the material ingested and assimilated by these organisms is still open. Khripounoff and Sibuet et al. (1980) suggested assimilation efficiencies of $15 \%$ for total organic carbon (TOC) and $22 \%$ for total nitrogen (TN) in some abyssal species. Likewise, Ginger et al. (2001) estimated assimilation efficiencies from 15 to $46 \%$ for TOC and from 11 to $53 \%$ for TON in four abyssal holothurians with different feeding strategies. Moreover, it is still largely unknown the contribution these large organisms make to the biogeochemical processes and organic matter cycling in deep-sea ecosystems.

The aim of our study is to understand the role of M. musculus in the ecosystem functioning (organic matter cycling) of the Nazaré Canyon at $3500 \mathrm{~m}$. To do so, we investigate the biochemical composition of potential food sources (in terms of proteins, carbohydrates and lipids) and estimate enzymatic digestion and potential utilization by $M$. musculus. In particular the following hypotheses were tested: a) is there a selective feeding on specific components of the sediment organic matter? b) Does the holothurian feeding play an important role in the biogeochemical cycling of organic matter in deep-sea sediments? In addition, owing to the high abundances of this deep-sea holothurian, we quantify the impact of holothurians on $\mathrm{C}$ and $\mathrm{N}$ cycling at mid-canyon depths.

\section{Material and methods}

\subsection{Study area}

The Nazare Canyon is a very narrow and elongated system. It extends for more than $210 \mathrm{~km}$, from the canyon head less than $1 \mathrm{~km}$ from the Portuguese coastline to the abyssal plain at $5000 \mathrm{~m}$ depth (Fig. 1). Unlike many submarine canyons, the Nazaré Canyon is not connected to a major river system. However, it is a major sediment pathway on the Portuguese margin (de Stigter et al., 2007). The sediment is predominantly of terrigenous silt and clay origin (Alt-Epping et al., 2007). The sediment is actively transported from the upper continental shelf to the canyon and out onto the abyssal plain by sediment gravity flows that occur on annual or longer timescales and are particularly vigorous during periods of winter storms (de Stigter et al., 2007; Masson et al., 2010). The currents flowing down the canyon lead to cycles of resuspension and deposition, alternating with intervals during which the sediment is deposited on the sea bed (de Stigter et al., 2007). The finer sediment resuspended by bottom currents, settles on the terraces adjacent to the thalweg, whereas sand and even coarser material generally travels through the canyon. In the upper and middle canyon there are moderately strong tidal currents (max. currents speeds up to $35 \mathrm{~cm} \mathrm{~s}^{-1}$ ) (de Stigter et al., 2007), which can cause sediment resuspension and consequently, transport and redistribution of particulate matter (Quaresma et al., 2007). 


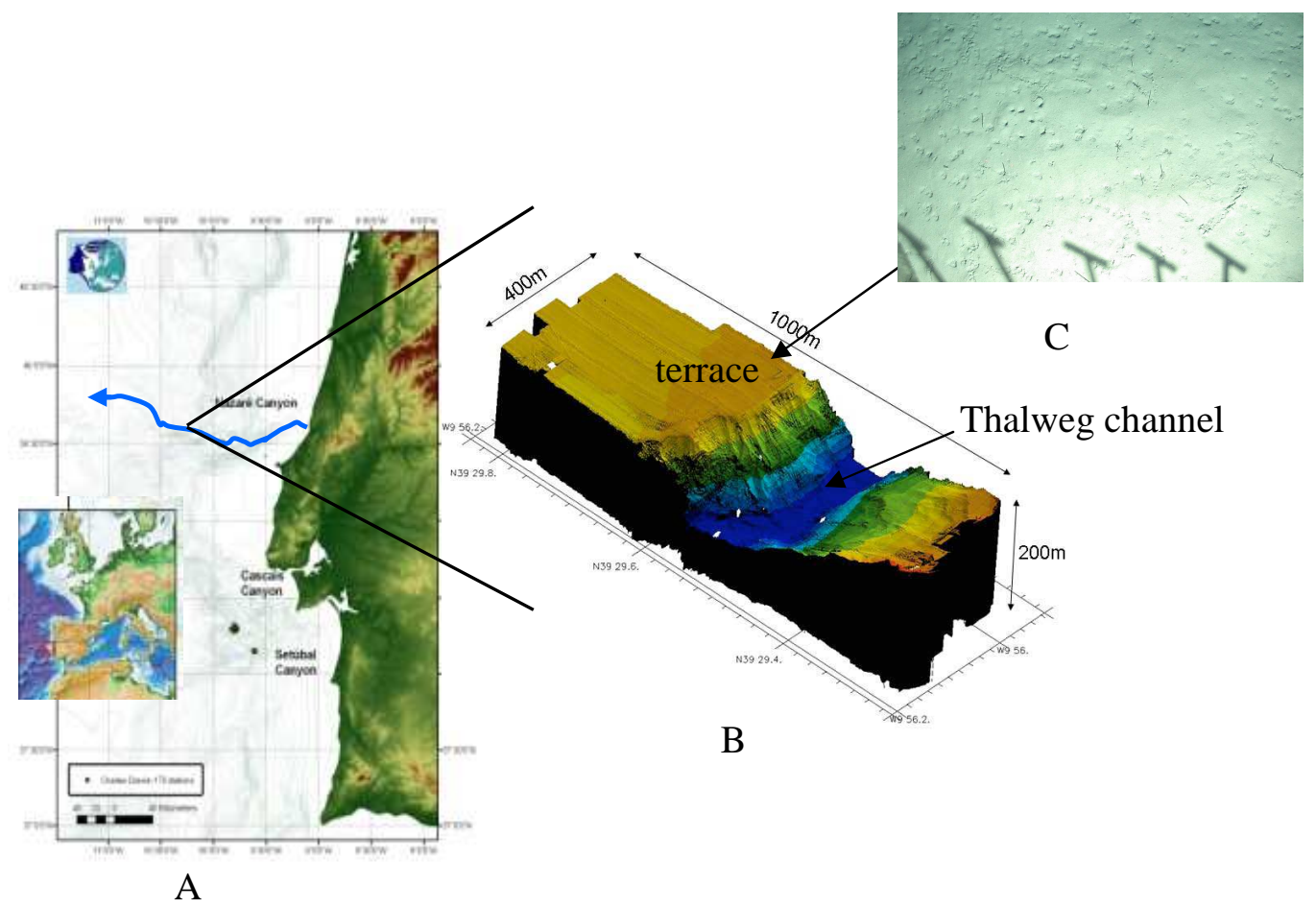

Fig. 1. Nazaré Canyon, $3500 \mathrm{~m}$ site. (A) Chart of the bathymetry of the Portuguese margin (GEBCO, 2003), showing the location the Nazaré Canyon; (B) ROV high resolution swath bathymetry of the central thalweg channel of the Nazaré canyon at $3500 \mathrm{~m}$. The steep channel wall is composed of rock outcrop. The channel floor has boulders with a thin drape of mud. (C) Terrace to the north of the thalweg is characterised by burrowing animals as seen by the burrows and feeding pits in the photograph (Modified after, Masson et al., 2010).

\subsection{Species studied}

Molpadia musculus (Phylum Echinodermata) is a subsurface deposit feeder holothurian and a mound builder. It spends its life orientated vertically or obliquely in the substrate, head downward, ingests the sediment at depth and excretes at the sea floor, thereby causing a significant upward transport of particles (i.e., a "conveyor belt feeder"; Rhoads, 1974). It has a stout body and a posterior region which narrows to form a "tail". There are no tube feet (Fig. 2). Species of the genus Molpadia inhabits muddy environments from shallow waters to abyssal depths (Rhoads and Young, 1971). These organisms feed head down in the sediment and use their tails to keep contact with the sediment surface (bioirrigation) (Pawson et al., 2001).

\subsection{Sampling}

Densities of M. musculus were determined using data collected during RRS Charles Darwin cruise 179 from 12 April to 17 May 2006. Five deployments were taken using an UKORS Megacorer (twelve multiple cylindrical cores of $0.008 \mathrm{~m}^{2}$ internal area each, for at total of approximately $0.1 \mathrm{~m}^{2}$ sampled per deployment) at ca. $3500 \mathrm{~m}$ (Table 1) in the Nazaré Canyon. Molpadiids were counted and their den- sity per $\mathrm{m}^{2}$ determined from replicated multicorers. Furthermore, the specimens were weighted and total biomass estimated as wet weight per $\mathrm{m}^{2}$.

Sediment samples, holothurians and their faecal material were collected using the Isis Remotely Operated Vehicle (ROV) at $3500 \mathrm{~m}$ in the Nazaré Canyon during the RRS James Cook cruise 10, from 3 June to 7 July 2007 (Table 1). Undisturbed sediment samples were collected with the push cores $(n=3)$ fitted with $57 \mathrm{~mm}$ inner diameter core tubes. Upon recovery, all cores were sliced at the following intervals: $0-1,1-3,3-5,5-10,10-15 \mathrm{~cm}$ and deep frozen at $-80^{\circ} \mathrm{C}$ until analysis. The water temperature at the sampling depth was approximately $3^{\circ} \mathrm{C}$.

As $M$. musculus individuals were not visible in ROV video footage of the seafloor, these specimens were collected with a ROV scoop that dug into the sediment. The mud collected at the same time as the holothurians was removed by shaking the scoop until the sediment fell away. A total of 10 holothurians were collected at the same location as the sediment samples (Table 1) and returned to the ship inside the bio-box attached to a retractable tool tray. Only intact animals were selected for the study. Once the ROV was back on board, M. musculus specimens were placed immediately at in situ temperature $\left(3^{\circ} \mathrm{C}\right)$, in a temperature-controlled laboratory. Each specimen was dissected in a sterilized Petri dish. 
Table 1. List of the stations data outlining the samples taken during cruises carried out on board the RV Charles Darwin and RV James Cook.

\begin{tabular}{llccccc}
\hline Station & Gear & Dive & Date & Latitude & Longitude & Depth $(\mathrm{m})$ \\
\hline CD56848\#1 & Megacorer & - & $08-05-2006$ & $39^{\circ} 30^{\prime} 00$ & $09^{\circ} 56^{\prime} 01$ & 3517 \\
CD56848\#2 & Megacorer & - & $08-05-2006$ & $39^{\circ} 30^{\prime} 00$ & $09^{\circ} 55^{\prime} 60$ & 3523 \\
CD56848\#3 & Megacorer & - & $09-05-2006$ & $39^{\circ} 29^{\prime} 24$ & $09^{\circ} 56^{\prime} 03$ & 3512 \\
CD56851\#1 & Megacorer & - & $09-05-2006$ & $39^{\circ} 29^{\prime} 24$ & $09^{\circ} 55^{\prime} 58$ & 3517 \\
CD56851\#2 & Megacorer & - & $09-05-2006$ & $39^{\circ} 29^{\prime} 24$ & $09^{\circ} 56^{\prime} 01$ & 3517 \\
CD56851\#3 & Megacorer & - & $10-05-2006$ & $39^{\circ} 29^{\prime} 24$ & $09^{\circ} 56^{\prime} 01$ & 3522 \\
CD56856\#1 & Megacorer & - & $11-05-2006$ & $39^{\circ} 29^{\prime} 24$ & $09^{\circ} 55^{\prime} 60$ & 3519 \\
CD56856\#2 & Megacorer & - & $11-05-2006$ & $39^{\circ} 30^{\prime} 00$ & $09^{\circ} 55^{\prime} 60$ & 3522 \\
JC10-090 & ISIS experiment & 46 & $09-06-2007$ & $39^{\circ} 29^{\prime} 82$ & $09^{\circ} 55^{\prime} 85$ & 3534 \\
JC10-091 & ISIS experiment & 48 & $12-06-2007$ & $39^{\circ} 29^{\prime} 82$ & $09^{\circ} 55^{\prime} 89$ & 3534 \\
JC10-099 & ISIS suction sampler & 50 & $13-06-2007$ & $39^{\circ} 29.85$ & $09^{\circ} 56^{\prime} 91$ & 3535 \\
JC10-099 & ISIS suction sampler & 50 & $14-06-2007$ & $39^{\circ} 29.52$ & $09^{\circ} 56^{\prime} 14$ & 3648 \\
JC10-099 & ISIS suction sampler & 50 & $14-06-2007$ & $39^{\circ} 29.53$ & $09^{\circ} 56^{\prime} 14$ & 3649 \\
JC10-099 & ISIS suction sampler & 50 & $14-06-2007$ & $39^{\circ} 29.53$ & $09^{\circ} 56^{\prime} 14$ & 3651 \\
JC10-106 & ISIS Push core & 51 & $15-06-2007$ & $39^{\circ} 29.76$ & $09^{\circ} 55^{\prime} 94$ & 3529 \\
JC10-106 & ISIS Push core & 51 & $15-06-2007$ & $39^{\circ} 29.76$ & $09^{\circ} 55^{\prime} 94$ & 3529 \\
JC10-106 & ISIS Push core & 51 & $15-06-2007$ & $39^{\circ} 29.76$ & $09^{\circ} 55^{\prime} 93$ & 3529 \\
JC10-106 & ISIS Push core & 51 & $15-06-2007$ & $39^{\circ} 29.77$ & $09^{\circ} 55^{\prime} 92$ & 3529 \\
JC10-106 & ISIS Push core & 51 & $15-06-2007$ & $39^{\circ} 29.76$ & $09^{\circ} 55^{\prime} 93$ & 3529 \\
\hline
\end{tabular}

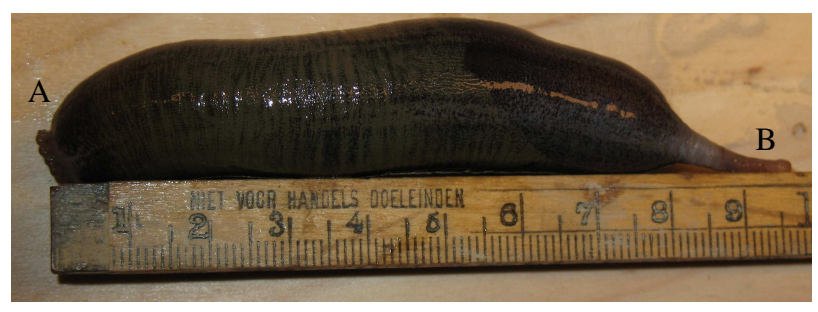

Fig. 2. A picture of a specimen of Molpadia musculus immediately after collection, when analysed for biometric variables. (A) mouth, (B) - tail.

The gut was opened and sediment samples were taken from three different parts of the gut (the oesophagus, the mid gut and the hind gut) making certain to exclude all gut tissues (see details in Roberts et al., 1996). Each sediment sample from the gut was transferred to a vial and stored at $-80^{\circ} \mathrm{C}$ until analysis.

Faecal material was collected during an in situ experiment placed on the seabed. The in situ experiment consisted of a circular chamber with 6 individual funnels that allowed each specimen to defecate to an individual sterilized vial. Five specimens were collected with the same method described above. At $3500 \mathrm{~m}$, each M. musculus was placed into an individual funnel. A sixth funnel was used as a control. Once each specimen was on the funnel, no evisceration or defecation was evident during the time of the set up of the experiment. The experiment lasted three days, the time necessary for these organisms to defecate (Amaro, personal observation). Once on board, the faecal material was collected in a sterilized vial attached to the end of each funnel and stored at $-80^{\circ} \mathrm{C}$.

\subsection{Analysis of potential food sources}

The protein, carbohydrate and lipid contents of 1) the sediments, 2) the material extracted from the gut and 3) the faecal material, were determined spectrophotometrically, and their concentrations were calculated from calibration curves of serum albumin, D-glucose and tripalmitine equivalents, respectively, and normalised to sediment dry weight (Pusceddu et al., 2009). For each biochemical assay, blanks were obtained using pre-combusted sediments $\left(450^{\circ} \mathrm{C}\right.$ for $\left.4 \mathrm{~h}\right)$. The detailed protocols are described in Danovaro (2010). All of the analyses were performed on three replicates, with approximately $0.2-1 \mathrm{~g}$ of wet sediment per sample.

Biopolymeric carbon was defined as the sum of the carbon equivalents of total proteins, carbohydrates and lipids (using conversion factors of $0.49,0.40$ and 0.75 , respectively) and has been often reported as the fraction of total organic $\mathrm{C}$ potentially available to benthic consumers (Fabiano et al., 1995; Danovaro et al., 2001; Dell' Anno et al., 2002, 2003).

As M. musculus feeds head down in the sediment, it was assumed that all of the biochemical compounds ingested by these holothurians occurred in the top $15 \mathrm{~cm}$ depth of the sediment. 
For all of the biochemical compounds, the digestion rate was estimated as the percentage of the difference in concentration between the oesophagus and hind gut. Based on the concentrations of the different biochemical compounds in the gut, faeces and sediment layers deeper than $1 \mathrm{~cm}$, we determined the concentration factor as the ratio between concentrations in the oesophagus and in the sediment.

\subsection{Analyses of exo-enzymatic activities}

Extracellular enzyme activities (aminopeptidase, $\beta$ glucosidase and alkaline phosphatase) were determined by cleavage of analogue fluorogenic substrates (L-Leucine4-methylcoumarinyl-7-amide, Leu-MCA; 4-MUF- $\beta$-Dglucopyranoside, MUF-Glu and 4-MUF-P-phosphate, MUF-P respectively; all substrates from SIGMA) as described in Danovaro et al. (1998). After evaluation of saturation concentrations, measurements were carried out in triplicate by adding $100 \mu \mathrm{l}$ of MUF-Glu and Leu-MCA (final concentration $200 \mu \mathrm{M}$ ) and $50 \mu \mathrm{l}$ of MUF-P (final concentration $50 \mu \mathrm{M}$ ) in a final volume of $5 \mathrm{ml}$ of seawater. Substrate incubations were performed in the dark at in situ temperature for $1 \mathrm{~h}$. Samples were analyzed fluorometrically (at $380 \mathrm{~nm}$ excitation, $440 \mathrm{~nm}$ emission for Leu-MCA and $365 \mathrm{~nm}$ excitation, $455 \mathrm{~nm}$ emission for MUF-Glu and MUF-P) as reported in Danovaro et al. (2005). The detailed protocols of all enzymatic analyses are described in Danovaro (2010). Data were normalized to dry weight $\left(60^{\circ} \mathrm{C}, 24 \mathrm{~h}\right)$ and reported as nanomoles of fluorescein released per gram of sediment per hour.

\subsection{Data analysis}

Differences in the quantity of the different potential food sources between different sediment layers were investigated by means of one-way analyses of variance (ANOVA). When significant differences were observed, then post-hoc Tukey's tests were performed. For all ANOVA and Tukey's tests, an alpha level of 0.05 was used as the threshold for statistical significance. Before the analyses, the homogeneity of variances was checked using the Cochran's C test. The Cochran test was not significant for any of the variables considered, so that the data were not transformed before analysis.

Since the measurements from the different trait guts and the faeces were most likely dependent on one another, thus hampering the application of parametric ANOVA tests, differences in the quantity of the different potential food sources (protein, carbohydrate, and lipid) in the different traits of the holothurians' gut and the faeces and the differences in the rates of extracellular enzymatic activities among the different traits of the holothurians' gut and the sediment were separately investigated by means of non-parametric KruskalWallis analyses of variance. The significant results were tested using a Mann-Whitney test, and the P-values corrected for multiple tests using a Bonferroni correction. Kruskal-
Wallis and Mann-Whitney tests were carried out using the Software STATISTICA 6.0.

The differences in 1) the biochemical composition (protein, carbohydrate and lipid) of the different sediment layers, 2) the biochemical composition and enzymatic activities within the holothurians gut material and 3) the top $\mathrm{cm}$ of the sediment, were then investigated by a distance-based permutational multivariate analysis of variance (PERMANOVA, Anderson, 2001; McArdle and Anderson, 2001). PERMANOVA was carried out using the PERMANOVA package included in the Primer 6+ software. The analysis was based on Euclidean distances of normalized data using 4999 random permutations of the appropriate units (Anderson and Ter Braak, 2003). The pseudo-multivariate variance components for each term in the model were calculated using direct multivariate analogues to the univariate ANOVA estimators (e.g., Searle et al., 1992).

\section{Results}

\subsection{Abundance and biomass of molpadiids holothurians}

Based on the number of organisms present in the total area sampled by the cores, we estimated a total abundance of $220 \pm 75.4$ (standard error) individuals per $\mathrm{m}^{2}$ and a total biomass of $473.1 \pm 16.9$ (standard error) $\mathrm{g}$ wet weight per $\mathrm{m}^{2}$.

\subsection{Analyses of potential food sources in sediments and in holothurian gut contents}

Vertical profiles of protein, carbohydrate, lipid and biopolymeric $\mathrm{C}$ concentrations in the top $15 \mathrm{~cm}$ of sediment are illustrated in Fig. 3. Proteins were the dominant biochemical compound $(70 \%$, on average of all sediment layers), followed by lipids (18\%) and carbohydrates (12\%). Total protein concentrations ranged from $10.76 \pm 0.63 \mathrm{mg} \mathrm{g}^{-1}$ in the top $\mathrm{cm}$ of the sediment to $5.11 \pm 0.80 \mathrm{mg} \mathrm{g}^{-1}$ in the 10 $15 \mathrm{~cm}$ layer.

Sedimentary protein content decreased significantly from the $0-1 \mathrm{~cm}$ layer to the deeper sediment layers (Table 2). No significant differences were observed between all other layers. Carbohydrate concentrations in the sediment ranged from $1.29 \pm 0.44 \mathrm{mg} \mathrm{g}^{-1}$ in the top $0-$ $1 \mathrm{~cm}$ layer to $1.51 \pm 0.31 \mathrm{mg} \mathrm{g}^{-1}$ in the $10-15 \mathrm{~cm}$ layer. There were no significant changes with increasing depth in the sediment (Table 2). Lipid concentrations ranged from $0.92 \pm 0.09 \mathrm{mg} \mathrm{g}^{-1}$ in the top $\mathrm{cm}$ of the sediment to $1.21 \pm 0.16 \mathrm{mg} \mathrm{g}^{-1}$ in the deepest sediment layer. No significant changes with increasing depth in the sediment were detected (Table 2). Biopolymeric $\mathrm{C}$ sediment content displayed the same trend as proteins with a significant difference between the top $1 \mathrm{~cm}$ and the rest of the sediment core 
Table 2. Results of the ANOVA (a) and PERMANOVA (b) tests carried out to ascertain differences in the quantity (ANOVA) and biochemical composition (PERMANOVA) of sediment OM with changing depth in the sediment of the Nazaré Canyon at $3500 \mathrm{~m}$ depth. DF $=$ degrees of freedom, $\mathrm{SS}=$ sum of squares; $\mathrm{MS}=$ mean square; $F=\mathrm{F}$ statistic; $P=$ probability level; $* * * P<0.001 ; * *=P<0.01$; SNK $=$ StudentNewman-Keuls post-hoc comparisons tests; ns = not significant; na = not applicable. Reported are also the results of the Cochran's C test: ns $=$ not significant.

\begin{tabular}{llrrrrrr}
\hline & Source & SS & DF & MS & $F$ & $P$ & SNK \\
\hline a) ANOVA & & & & & & & \\
\hline Protein & Depth & 71.94 & 4 & 17.99 & 30.92 & $* * *$ & $1>2-5$ \\
Cochran's C = 0.5549 (ns) & Residual & 5.82 & 10 & 0.58 & & & \\
& Total & 77.76 & 14 & & & & \\
Carbohydrate & Depth & 0.25 & 4 & 0.06 & 0.21 & ns & na \\
Cochran's C = 0.4102 (ns) & Residual & 2.96 & 10 & 0.30 & & & \\
& Total & 3.21 & 14 & & & & \\
Lipid & Depth & 0.20 & 4 & 0.05 & 1.23 & ns & \\
Cochran's C = 0.3340 (ns) & Residual & 0.41 & 10 & 0.04 & & & \\
& Total & 0.61 & 14 & & & & \\
Biopolymeric C & Depth & 16.20 & 4 & 4.05 & 7.45 & $* *$ & $1>2-5$ \\
Cochran's C = 0. 4990 (ns) & Residual & 5.44 & 10 & 0.54 & & & \\
& Total & 21.63 & 14 & & & & \\
\hline b) PERMANOVA & & & & & & & \\
\hline Depth in the sediment & 4 & 1025.10 & 256.27 & 16.61 & $* *$ & & \\
Residual & 10 & 154.28 & 15.428 & & & & \\
Total & 14 & 1179.30 & & & & & \\
\hline
\end{tabular}

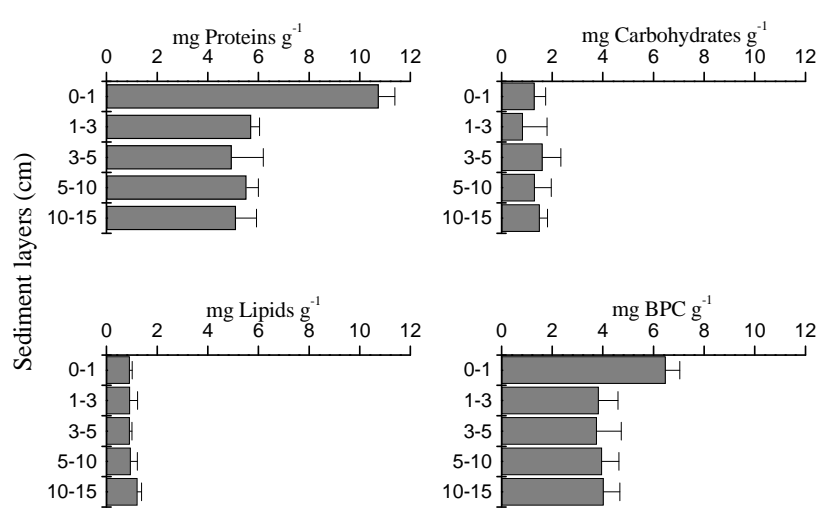

Fig. 3. Vertical distributions of the main biochemical classes of organic compounds (proteins, carbohydrates, lipids) and biopolymeric C (the sum of carbon within these compounds) in the sediment. Standard deviations are indicated. Data are expressed in milligrams per $\mathrm{g}$ of sediment dry weight $(n=3)$.

(Table 2). As for the different classes of organic compounds, no significant differences were observed between the layers from 1 to $15 \mathrm{~cm}$ depth in the sediment core.

\subsection{Organic matter in holothurians guts and faeces}

Changes in protein, carbohydrate and lipid contents through the gut and in the faeces of M. musculus are illustrated in Fig. 4. Protein concentrations ranged from $17.05 \pm 3.26 \mathrm{mg} \mathrm{g}^{-1}$ in the oesophagus to $5.57 \pm 0.83 \mathrm{mg} \mathrm{g}^{-1}$ in the faeces. In all holothurians gut tracts and in the faeces, protein content was 5 to 17 times greater than the other biochemical compounds. Protein concentrations decreased progressively from the oesophagus to the mid- and end-gut and the faeces (Table 3, Mann-Whitney test). Carbohydrate content ranged from $1.85 \pm 0.64 \mathrm{mg} \mathrm{g}^{-1}$ in the oesophagus to $2.24 \pm 0.34 \mathrm{mg} \mathrm{g}^{-1}$ in the mid gut, and $1.38 \pm 0.29 \mathrm{mg} \mathrm{g}^{-1}$ in the faeces, but there were no significant differences between the different gut sections and the faeces (Table 3). Lipid concentrations varied from $2.14 \pm 0.68 \mathrm{mg} \mathrm{g}^{-1}$ in the oesophagus to $3.97 \pm 0.75 \mathrm{mg} \mathrm{g}^{-1}$ in the mid gut and to $1.02 \pm 0.11 \mathrm{mg} \mathrm{g}^{-1}$ in the faeces, and displayed values in the mid-gut significantly higher than in the other holothurians gut traits and in the faeces (Table 3, Mann-Whitney test). Biopolymeric C concentrations ranged from $10.70 \pm 2.24 \mathrm{mg} \mathrm{g}^{-1}$ in the oesophagus to $4.04 \pm 0.61 \mathrm{mg} \mathrm{g}^{-1}$ in the faeces. 
Table 3. Results of the Kruskal-Wallis ANOVA (a) and PERMANOVA (b) tests carried out to ascertain differences in the quantity (ANOVA) and biochemical composition (PERMANOVA) of sediment OM among the various sections of the holothurians' gut and the faeces. DF = degrees of freedom, $H=$ Kruskal-Wallis $\mathrm{H}, P=\mathrm{P}$-level, $\mathrm{SS}=$ sum of squares; $\mathrm{MS}=$ mean square; $F=\mathrm{F}$ statistic; $P=$ probability level; $* * *=P<0.001$ Oesophagus: first part of the gut; mid gut: second part of the gut; others: nd gut and faeces (see material and methods for details). P-level for non parametric ANOVA were Bonferroni corrected.

\begin{tabular}{|c|c|c|c|c|c|c|}
\hline Variable & $\mathrm{DF}$ & $H$ & $P$ & \multicolumn{3}{|c|}{ Mann-Whitney test } \\
\hline \multicolumn{7}{|c|}{ a) Kruskall-Wallis ANOVA } \\
\hline \multirow{3}{*}{$\begin{array}{l}\text { Protein } \\
\text { Carbohydrate } \\
\text { Lipid }\end{array}$} & 3 & 9.462 & 0.024 & \multirow{3}{*}{\multicolumn{3}{|c|}{$\begin{array}{l}\text { Oesophagus }>\text { mid-gut }>\text { End-gut }=\text { Faeces } \\
\text { Not applicable } \\
\text { Mid gut }>\text { Oesophagus }=\text { End-gut }>\text { Faeces }\end{array}$}} \\
\hline & 3 & 5.051 & ns & & & \\
\hline & 3 & 9.359 & 0.025 & & & \\
\hline \multicolumn{2}{|c|}{ Source } & $\mathrm{DF}$ & SS & MS & Pseudo-F & $P$ \\
\hline \multicolumn{7}{|c|}{ b) PERMANOVA } \\
\hline \multicolumn{2}{|c|}{ Gut section/faeces } & 3 & 267.15 & 89.052 & 17.161 & $* * *$ \\
\hline \multicolumn{2}{|c|}{ Residual } & 8 & 41.513 & 51.891 & & \\
\hline \multicolumn{2}{|c|}{ Total } & 11 & 308.67 & & & \\
\hline
\end{tabular}

Based on the concentrations of the different biochemical compounds in the gut, faeces and sediment layers deeper than $1 \mathrm{~cm}$, we determined the concentration factor as the ratio between concentrations in the oesophagus and in the sediment. The concentration factor of proteins in the oesophagus was approximately 3.1. For carbohydrate and lipid the concentration factors were approximately 1.3 and 2.0, respectively. The mean concentration of biopolymeric $\mathrm{C}$ in the oesophagus was approximately 2.7 greater than in the sediment.

Digestion rates of the different biochemical compounds were then calculated as the difference in concentration between the material in the oesophagus and that in the faeces. These calculations revealed that proteins had the highest digestion rate $(67 \pm 1 \%)$, followed by carbohydrates $(50 \pm 11 \%)$ and lipids $(23 \pm 11 \%)$. Overall, biopolymeric C digestion rate was $62 \pm 3 \%$ (Fig. 5).

\subsection{Enzymatic activities}

Changes in extracellular enzymatic activities within the holothurians gut are presented in Fig. 6. The KruskallWallis tests revealed that the rates of the three investigated activities displayed significant differences between the different gut traits and the sediment (Table 4). In particular, rates of aminopeptidase activity in the mid gut were significantly higher than in the other traits and the sediment (MannWhitney test, $P<0.05$ for all comparisons, after Bonferroni correction), whereas $\beta$-glucosidase activity rates were lower in the end gut than in the other gut traits and in the sediment (Mann-Whitney test, $P<0.05$ for all comparisons, after Bonferroni correction). Alkaline phosphatase activity rates decreased progressively from the oesophagus-mid gut to the end gut and the sediment (Mann-Whitney test, $P<0.05$ for all comparisons, after Bonferroni correction).
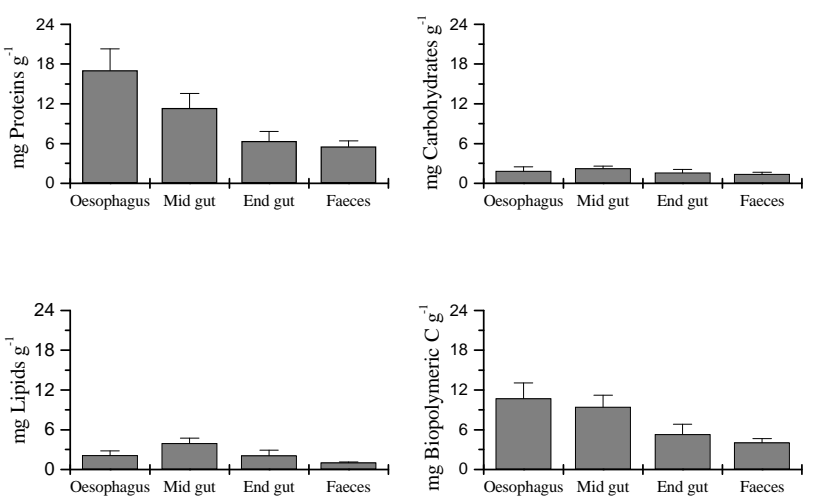

Fig. 4. Distributions of the main biochemical classes of organic compounds (proteins, carbohydrates, lipids) and biopolymeric $\mathrm{C}$ through the gut of M. musculus (oesophagus, mid gut, hind gut and faeces). Standard deviations are indicated. Data are expressed in milligrams per $\mathrm{g}$ of sediment dry weight $(n=3)$.

\subsection{Potential contamination of holothurian gut contents}

Previous studies pointed out that the operations of gut content extraction can determine the contamination of subsequent biochemical analyses (FitzGeorge-Balfour et al., 2010), as a result of unregulated lipolysis of phospholipids within the digestive tissue resulting from the death of organisms on recovery (Ginger et al., 2001). This would limit the use of biomarkers in gut contents, which are also present in the organisms tissues, to determine feeding selectivity in deep-sea organisms (Hudson et al., 2003; Wigham et al., 2003; Howell et al., 2004). However, it is worthy of notation that in the present study, we report that the biochemistry of the gut contents of $M$. musculus closely reflects that of the sediments, 
Table 4. Results of the Kruskal-Wallis ANOVA (a) and PERMANOVA (b) tests carried out to ascertain differences in extracellular enzymatic activities among the various sections of the holothurians' gut (ANOVA and SNK tests) and between the gut and the sediment. DF $=$ degrees of freedom, $\mathrm{SS}=$ sum of squares; $\mathrm{MS}=$ mean square; $F=\mathrm{F}$ statistic; $P=$ probability level; $* *=P<0.01$; ns $=$ not significant; na $=$ not applicable.

\begin{tabular}{|c|c|c|c|c|c|c|}
\hline Variable & $\mathrm{DF}$ & $H$ & $P$ & \multicolumn{3}{|c|}{ Mann-Whitney test } \\
\hline \multicolumn{7}{|c|}{ a) Kruskall-Wallis ANOVA } \\
\hline \multirow{3}{*}{$\begin{array}{l}\text { Aminopeptidase } \\
\beta \text {-glucosidase } \\
\text { Alkaline phosphatase }\end{array}$} & 3 & 9.154 & 0.027 & \multirow{3}{*}{\multicolumn{3}{|c|}{$\begin{array}{l}\text { Mid gut }>\text { Oesophagus }=\text { End gut }=\text { sediments } \\
\text { End gut }<\text { Oesophagus }=\text { Mid gut }=\text { Faeces } \\
\text { Oesophagus }=\text { Mid gut }>\text { End gut }>\text { Faeces }\end{array}$}} \\
\hline & 3 & 8.128 & 0.043 & & & \\
\hline & 3 & 9.492 & 0.023 & & & \\
\hline \multicolumn{2}{|l|}{ Source } & $\mathrm{DF}$ & SS & MS & Pseudo-F & $P$ \\
\hline \multicolumn{7}{|c|}{ b) PERMANOVA } \\
\hline \multicolumn{2}{|c|}{ Gut/sediment } & 3 & $2.22 \mathrm{E}+10$ & $7.39 \mathrm{E}+09$ & 64.123 & $* *$ \\
\hline \multicolumn{2}{|c|}{ Residual } & 8 & $9.21 \mathrm{E}+09$ & $1.15 \mathrm{E}+09$ & & \\
\hline \multicolumn{2}{|l|}{ Total } & 11 & $3.14 \mathrm{E}+10$ & & & \\
\hline
\end{tabular}

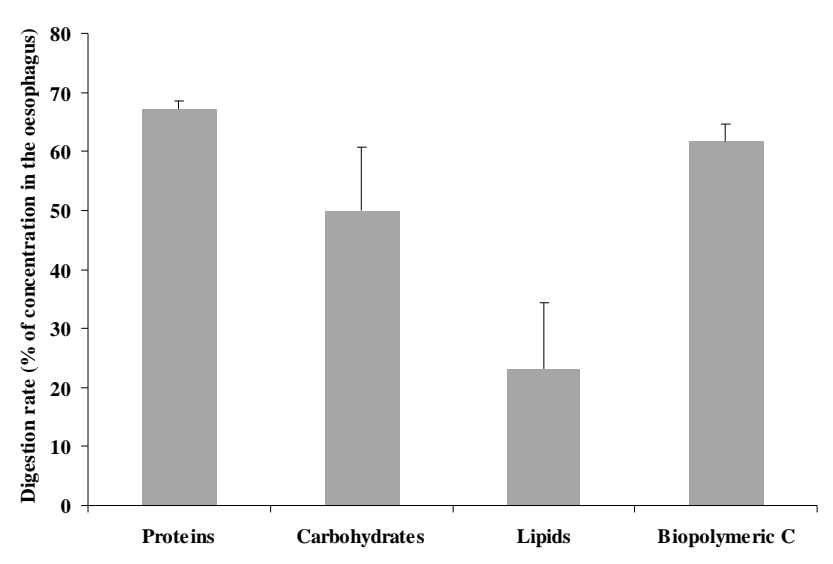

Fig. 5. Digestion rate in $\%$ of the main biochemical classes of organic compounds (proteins, carbohydrates, lipids) and biopolymeric $\mathrm{C}$ in $M$. musculus. Standard deviations are indicated. Data are mg per $\mathrm{g}$ of sediment dry weight $(n=3)$.

suggesting a negligible effects of contamination induced by gut content extraction.

\section{Discussion}

Deep-sea holothurians are common in most deep-sea soft bottoms and dominate the megafaunal abundance and biomass over large parts of the deep-sea floor (Sibuet et al., 1982; Billett, 1991; Roberts et al., 2000). In recent years, large scale changes have been noticed in the density of abyssal megafauna species both in the NE Atlantic (Billett et al., 2001) and NE Pacific (Lauermann et al., 1996; Ruhl and Smith, 2004). Significant effects have been observed in the process of OM on the seabed when species
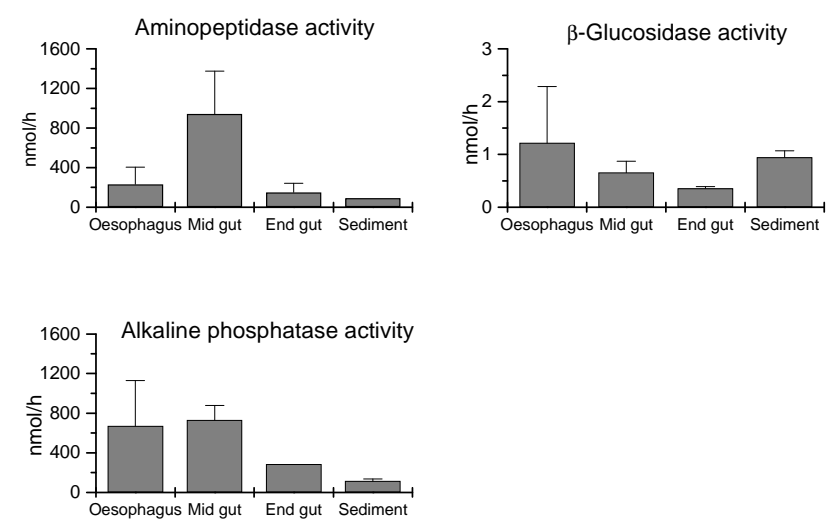

Fig. 6. Distributions of aminopeptidase, $\beta$-glucosidase and alkaline phosphatase activity through the gut of $M$. musculus and in sediment samples. Standard deviations are indicated. Data are expressed in nanomole of substrated released per $\mathrm{g}$ of sediment dry weight per hour $(n=3)$.

changed in density (Bett et al., 2001; de Leo, et al., 2010). Although the reason for such a rise in the holothurians abundance is still uncertain, it is possible to hypothesise that this phenomenon is associated with changes in phytoplankton community structure and changes in quantity and quality of the POC flux to the abyssal seafloor (Wigham et al., 2003; Ruhl et al., 2004; Smith et al., 2006, 2008; Billett et al., 2010). Such changes will in turn affect the structure and function of deep-sea ecosystems (Smith et al., 2008). In the present study, very high abundances of the infaunal holothurian M. musculus were found at $3500 \mathrm{~m}$ in the Nazaré Canyon. For comparison, Molpadia blakei was found with abundances of ca. 0.0044 ind. per $\mathrm{m}^{2}$ at depths of ca. $3900 \mathrm{~m}$ at the PAP site (Billett, 1991). In contrast, the 
abundances here were $220 \pm 75.4$ ind. per $\mathrm{m}^{2}$ with a biomass of $0.473 \pm 0.017 \mathrm{~kg}$ per $\mathrm{m}^{2}$, which is unprecedented in deepsea infaunal holothurians. In the Kaikoura Canyon, molpadiids biomass was similar to the biomass estimated here, averaging $0.65 \mathrm{~kg}$ per $\mathrm{m}^{2}$ (de Leo et al., 2010). To investigate the potential food sources that might sustain such a large population, the biochemical composition of the sediment, the holothurians' gut contents and holothurians' faecal material were analysed. We used the labile portion of $\mathrm{OM}$ in the sediment as the possible food source for these organisms. This labile portion of OM mainly consists of simple and/or combined compounds (i.e. biopolymers) like proteins, carbohydrates and lipids, which are rapidly mineralised (Danovaro et al., 2001; Pusceddu et al., 2009). Organic matter in the sediments where $M$. musculus exists in high densities is composed mainly by proteins, followed by carbohydrates and lipids (Fig. 3). High concentrations of proteins (and biopolymeric C) were found in the top 0-1 cm layer and despite a significant decrease to $1-3 \mathrm{~cm}$ layer, large quantities were observed also down to $15-\mathrm{cm}$ depth in the sediment core. For comparison, at the PAP site, sedimentary protein concentrations (up to approximately $1.5 \mathrm{mg} \mathrm{g}^{-1}$ in the top $0.5 \mathrm{~cm}$; Danovaro et al., 2001) were about seven-folds lower than those reported in the present study $\left(10.7 \pm 0.6 \mathrm{mg} \mathrm{g}^{-1}\right.$ in the top 1st centimetre). In other studies, the availability of proteins in deep-sea sediments was even lower than the one mentioned above (Sibuet, 1984; Pfannkuche and Thiel, 1987; Danovaro et al., 1993; Boetius et al., 1996; Tselepides et al., 2000). Carbohydrates and lipids were in the same range as for the PAP deep-sea sediments (Danovaro et al., 2001). Although we did not measure $\mathrm{C}$ and $\mathrm{N}$ sediment contents, having thus no possibility to ascertain the "freshness" of the organic material in the sediment using $\mathrm{C} / \mathrm{N}$ ratios (Meyers, 1994), we report here that values of the protein to carbohydrate ratio in the Nazare Canyon at $3500 \mathrm{~m}$ depth were $9.07 \pm 0.97$ in the top centimeter. Values of the protein to carbohydrate ratio in deep-sea sediments range from $<0.1$ in the oligotrophic Eastern Mediterranean Sea (500-2400 m depth, Danovaro et al., 1993) to $0.7-0.9$ at the PAP (at $4850 \mathrm{~m}$ depth; Danovaro et al., 2001). Values of this ratio in marine sediments display also generally higher values immediately after the deposition of phyto-detritus on the seafloor and decrease when highest flux rates of carbohydrate-enriched material are observed (Tselepides et al., 2000; Fabiano et al., 2001).

This indicates that the subsurface sediment layers of the Nazaré Canyon are characterised by a relatively large availability of compounds with high nutritional quality (i.e. $\mathrm{N}$ rich). These results were consistent with previous studies that reported that sediments here are enriched in OM and chlorophyll-a and present a significant accumulation of labile and high quality $\mathrm{OM}$, compared with other sites along the Portuguese margin and canyons in the Mediterranean regions (Danovaro et al., 1999; Tselepides et al., 2000; García and Thomsen, 2008; García et al., 2008; Amaro et al., 2009;
Pusceddu et al., 2010). The Nazaré Canyon displayed sediment accumulation rates higher than those found in other regions located along the west Iberian continental slope (between 5 and $17 \mathrm{~mm} \mathrm{y}^{-1}$ on various different terraces) (de Stigter et al., 2007; Arzola et al., 2008; Masson et al., 2010, Pusceddu et al., 2010). The rates found at ca. 3,500 m are higher than expected for these depths $\left(14 \mathrm{~mm} \mathrm{y}^{-1}\right)$ and are closer to those found in the canyon head (de Stigter et al., 2007). This suggests this part of the canyon to be a midcanyon depocenter of sediment and OM (Arzola et al., 2008; Masson et al., 2010). The cause for this is still unknown, however it is thought to be related to a number of regional oceanographic and local climatic processes like wind, internal waves, tidal currents (Schmidt et al., 2001; Vitorino et al., 2002a, b; Canals et al., 2006; Masson et al., 2010), floods and storms (de Stigter et al., 2007), which have been observed in other deep-sea canyons along the European continental margins (Pusceddu et al., 2010). The export of organic C from the upper to the mid part of the canyon is a recurrent mechanism fuelling the benthos of this area with a significant amount of OM of high nutritional quality. For example, an accumulation of labile organic compounds on the seabed is often associated with unprecedented abundance, biomass and biodiversity of metazoan meiofauna (Danovaro et al., 2002, 2003; Gambi et al., 2003).

The gut of a holothurian can be considered as a bioreactor (Penry and Jumars, 1986, 1987; Jumars, 2000), in which the animals quickly extract assimilable food from the ingested sediments. A wide spectrum of hydrolytic gut enzymes has evolved to fit the diet of each species, reflecting the types of food items that are available in the sediment (Féral, 1989).

Sibuet et al. (1982), investigating the trophodynamics of the holothurians Deima validum validum and Pseudostichopus villosus from the Demera Abyssal Plain, estimated assimilation efficiencies of ca. $18 \%$ for proteins, ca. $2.7 \%$ for carbohydrates and ca. $1.1 \%$ for lipids. A total of ca. $22.3 \%$ and $20.5 \%$ of the ingested material was assimilated by $D$. validum validum and $P$. villosus, respectively. In our study we found high concentrations of proteins in the oesophagus of M. musculus (5-17 times higher than the other biochemical compounds) while lipids and carbohydrates were present in low concentrations (Fig. 4). Protein concentrations decreased significantly between the oesophagus and the rest of the holothurian gut, concomitantly with the highest aminopeptidase activities found in the mid gut (Fig. 6). This enzyme is responsible for the hydrolysis of proteins, breaking them down into oligomers which are more easily assimilated by the animal (Roberts et al., 2001). We believe that the mid gut is the portion of the holothurians where the highest fraction (approximately $33 \pm 1 \%$ ) of the proteins is digested, with a final digestion rate equal to $67 \pm 1 \%$. Carbohydrates and lipids were not removed in the mid gut, but were preferentially digested in the end gut, with final digestion rates equal to $50 \pm 11 \%$ and $23 \pm 11 \%$, respectively (Figs. 4, 5, 6 ). This result reflects the preferential utilization of organic 
$\mathrm{N}$ and lipids in the dietary requirement of these holothurians. Moreover, the significantly higher alkaline phosphatase activity in the oesophagus and mid gut when compared to the hind gut (Figs. 4, 6) supports the hypothesis of a potential and quick exploitation of organic $\mathrm{P}$ in the mid gut. Phosphatase activity contributes to degradation and cycling of organic phosphorus. The activity of this enzyme has been found to be consistently high in abyssal holothurians (Roberts et al., 2001). Therefore holothurians could also play an important role in phosphorus cycling in deep-sea sediments.

Previous studies have hypothesized a key role of the prokaryotic biomass in the diet of deep-sea holothurians (Deming and Colwell, 1982; Sibuet et al., 1982; Roberts et al., 2001; Amaro et al., 2009). However, overall prokaryotic biomass contributed for less than $0.1 \%$ of the total protein absorbed (Amaro, personal observation). Holothurians would appear not to rely on microbes for their direct nutrition. However, prokaryote activity on organic substrates might indirectly provide essential nutrients (Deming and Colwell, 1982; Eardly et al., 2001).

Deposit-feeders may have two ways to ingest and assimilate food using foraging and digestive strategies, which involve: 1) particle selection, in which the organism preferentially selects food-rich particles during the pickup and ingestion (Billett et al., 1988; Levin et al., 1997; Ferner and Jumars, 1999), and 2) assimilatory selection in which the organism selectively digests and/or assimilates food in its guts (Penry and Jumars, 1990; Mayer et al., 1997; Jumars, 2000). Based on the composition and concentration of biochemical compounds in the sediment and in the oesophagus, we determined the average food selection. In our study, we estimated the average concentration of biopolymeric $\mathrm{C}$ in the oesophagus of M. musculus as being approximately 3-times greater than in the sediment. However, this concentration factor might depend on season (Billett et al., 1988). Radiocarbon data (a proxy for labile OM) suggest that M. musculus has a low particle selection index and high digestive selection index (McClintic et al., 2008; Puriton et al., 2008). This observation is in agreement with, Miller et al. (2000), who found labile material in the guts of molpadiids using the tracer ${ }^{234} \mathrm{Th}$. These authors concluded that molpadiids either feed on very rich subsurface sediments or are able to catch labile surface sediments down into their burrows. Assuming that M. musculus is a head-down feeder like Molpadia oolitica (Rhoads and Young, 1971) we hypothesize that in the Nazaré Canyon, M. musculus has a high efficiency in exploiting sedimentary proteins and complements its feeding requirements with an optimal foraging strategy.

At the time of sampling, given the average abundance to be $220 \pm 75.4$ ind. $\mathrm{m}^{-2}$, the population of M. musculus at $3500 \mathrm{~m}$ depth in the Nazaré Canyon could remove ca. $0.49 \pm 0.13 \mathrm{~g} \mathrm{C}$ and $0.13 \pm 0.03 \mathrm{~g} \mathrm{~N} \mathrm{~m}^{-2} \mathrm{~d}^{-1}$ from the sediment. However, we cannot disregard the importance of other deep-sea benthic species that have been found in large numbers in this system. For instance, the holothurian $Y p$ - silothuria bitentaculata (Ludwig, 1893) has abundances of 136 ind. $\mathrm{m}^{-2}$ in the same location as M. musculus (Amaro, personal observation). Ypsilothuria bitentaculata is a surface-deposit feeder that could be responsible for exploiting food-rich particles from surficial sediments and may have higher particle selectivity than M. musculus. The presence of large numbers of these two species in the same deep-sea system can be explained either by the establishment of an ecological coexistence permitted by their different feeding strategies (horizontal vs. vertical feeding of $Y$. bitentaculata and M. musculus, respectively), either by an excess of food availability. Whatever the factor or combination of factors allowing coexistence, these two deposit-feeding holothurians have therefore the potential to impact the remaining benthic community through the depletion of available sources to other organisms while influencing the trophic strategy of one other. Deep-sea megafauna are the primary consumers of fresh food and phytodetritus and may possess a competitive advantage over taxa when foraging for it (Billett et al., 2010). Macrofauna preferentially rework the food that arrives on the seabed, ahead of the meiofauna and bacteria (Witte et al., 2003). These animals can be very active when contributing to sediment reworking and potentially influencing other infaunal assemblages through bioturbation and remineralization (Ruhl and Smith, 2004). Smallwood et al. (1999), Ginger et al. (2001) and Witbaard et al. (2001), suggested that megafauna can significantly affect the food resources available to the rest of the benthos. McClain and Barry (2010) also suggested that megafauna are important habitat modifiers in the deep sea affecting macrofauna biodiversity. They showed a high fauna turnover and changes in the community structure at scales $<100 \mathrm{~m}$, and often $<10 \mathrm{~m}$ related to geographic features on the Monterey Canyon. Macrofauna biodiversity values are lower in the sediments characterised by the presence of $M$. musculus and Y. bitentaculata than in other Nazaré Canyon areas (Cunha, personal observation). We conclude that the impact of M. musculus affects not only the degradation of OM, but its redistribution and availability for other fauna at specific locations of the seafloor in the largest submarine canyon of the European margins. Our data also show that the sediment from the faeces still contain a considerable amount of biopolymeric $\mathrm{C}$ $\left(4.04 \pm 0.61 \mathrm{mg} \mathrm{g}^{-1}\right)$. Although this value may be overestimated, as the faecal material may contain artifacts due to disturbance or handling of the experiment, it is still important to note that faeces may be important in the redistribution of OM. This consequently, will affect the infaunal community. In summary we suggest that whilst feeding, these deep-sea holothurians, play a potentially important role in sediment mixing and modify the structure and geochemistry, mineralisation of sediments. Thus, they appear to be key ecosystem engineers within the Nazaré Canyon. 
Acknowledgements. This research was partially supported by the HERMES project, EC contract no GOCE-CT-2005-511234, funded by the European Commission's Sixth Framework Programme under the priority "Sustainable Development, Global Change and Ecosystems". This study was supported by a grant (SFRH/BPD/21459/2005) awarded by Fundação Para a Ciência e Tecnologia (FCT) to Teresa Amaro. The officers and crew of RRS James Cook and Ben Boorman are acknowledged for their help in collecting the samples.

Edited by: J. Middelburg

\section{References}

Accornero, A., Picon, P., de Bovee, F., Charriere, B., and Buscail, R.: Organic carbon budget at the sediment-water interface on the Gulf of Lions continental margin, Cont. Shelf Res., 23, 79-92, 2003.

Alt-Epping, U., Mil-Homens, M., Hebbeln, D., Abrantes, F., and Schneider, R. R.: Provenance of organic matter and nutrient conditions on a river- and upwelling influenced shelf: A case study from the Portuguese Margin, Mar. Geol., 243, 169-179, 2007.

Amaro, T., Witte, H., Herndl, G. J., Cunha, M. C., and Billett, D. S. M.: Deep-sea bacterial communities in sediments and guts of deposit-feeding holothurians in Portuguese canyons (NE Atlantic), Deep-Sea Res. I, 56, 1834-1843, 2009.

Anderson, M. J.: A new method for non-parametric multivariate analysis of variance, Aust. J. Ecol., 26, 32-46, 2001.

Anderson, M. J. and ter Braak, C. J. F.: Permutation tests for multifactorial analysis of variance, J. Stat. Comp. Simul., 73, 85-113, 2003.

Arzola, R. G., Wynn, R. B., Lastras, G., Masson, D. G., and Weaver, P. P. E.: Sedimentary features and processes in the Nazaré and Setúbal submarine canyons, west Iberian margin, Mar. Geol., 250(1-2), 64-88, 2008.

Bett, B. J., Malzone, M. G., Narayanaswamy, B. E., and Wigham, B. D.: Temporal variability in phytodetritus and megabenthic activity at the seabed in the deep Northeast Atlantic, Prog. Oceanogr., 50, 349-368, 2001.

Bianchelli, S., Gambi, C., Pusceddu A., and Danovaro, R.: Trophic conditions and meiofaunal assemblages in the Bari Canyon and the adjacent open slope (Adriatic Sea), Chem. Ecol., 24, 101109, 2008.

Billett, D. S. M., Llewellyn, C., and Watson, J.: Are deep-sea holothurians selective feeders?, in: Echinoderm Biology, edited by: Burke, R., Maldenov, P., Lambert, P., and Parsley, R., Balkema, Rotterdam, 421-429, 1988.

Billett, D. S. M.: Deep-sea holothurians, Oceanogr. Mar. Biol. Annu. Rev., 29, 259-317, 1991.

Billett, D. S. M., Bett, B. J., Rice, A. L., Thurston, M. H., Galéron, J., Sibuet, M., and Wolff, G. A.: Long-term change in the megabenthos of the Porcupine Abyssal Plain (NE Atlantic), Prog. Oceanogr., 50, 325-348, 2001.

Billett, D. S. M., Bett, B. J., Reid, W. D. K., Boorman, B., and Priede, M.: Long-term change in the abyssal NE Atlantic: The 'Amperima Event' revisited, Deep-Sea Res. II, 57, 1406-1417, 2010.

Boetius, A., Scheibe, S., Tselepides, A., and Thiel, H.: Microbial biomass and activities in deep-sea sediments of the Eastern
Mediterranean: trenches are benthic hotspots, Deep-Sea Res, 43, 1439-1460, 1996.

Canals, M., Puig, P., Durrieu de Madron, X., ,Heussner, S., Palanques, A., and Fabres, J.: Flushing submarine canyons, Nature, 444, 354-357, 2006.

Danovaro, R.: Methods for the Study of Deep-Sea Sediments, Their Functioning and Biodiversity, CRC Press, Boca Raton, 428 pp., 2010.

Danovaro, R., Fabiano, M., and Della Croce, N.: Labile organic matter and microbial biomasses in deep-sea sediments (Eastern Mediterranean Sea), Deep-Sea Res. I, 40, 953-965, 1993.

Danovaro, R., Marrale, D., Della Croce, N., Dell'Anno, A., and Fabiano, M.: Heterotrophic nanoflagellates, bacteria, and labile organic compounds in continental shelf and deep-sea sediments of the eastern Mediterranean, Microb. Ecol., 35, 244-255, 1998.

Danovaro, R., Dinet, A., Duineveld, G., and Tselepides, A.: Benthic response to particulate fluxes in different trophic environments: a comparison between the Gulf of Lions-Catalan Sea (W Mediterranean) and the Cretan Sea (E Mediterranean), Prog. Oceanogr., 44, 287-312, 1999.

Danovaro, R., Dell'Anno, A., and Fabiano, M.: Bioavailability of organic matter in the sediments of the Porcupine Abyssal Plain, northeastern Atlantic, Mar. Ecol. Prog. Ser., 220, 25-32, 2001.

Danovaro, R., Gambi, C., and Della Croce, N.: Meiofauna hotspot in the Atacama Trench, eastern South Pacific Ocean, Deep-Sea Res. I, 49, 843-857, 2002.

Danovaro, R., Della Croce, N., Dell'Anno, A., and Pusceddu, A.: A depocenter of organic matter at 7800-m depth in the Atacama trench sediments (SE Pacific Ocean), Deep-Sea Res. I, 50, 14111420, 2003.

Danovaro, R., Armeni, M., Luna, G. M., Corinaldesi, C., and Dell'Anno, A.: Exo-enzymatic activities and dissolved organic pools in relation with mucilage development in the Northern Adriatic Sea, Sci. Total Environ., 353, 189-203, 2005.

Danovaro, R., Dell'Anno, A., Corinaldesi, C., Magagnini, M., Noble, R., Tamburini, C., and Weinbauer, M.: Major viral impact on the functioning of benthic deep-sea ecosystems, Nature, 454, 1084-1087, 2008a.

Danovaro, R., Gambi, C., Dell'Anno, A., Corinaldesi, C., Fraschetti, S., Vanreusel, A., Vincx, M., and Gooday, A. J.: Exponential decline of deep-sea ecosystem functioning linked to benthic biodiversity loss, Curr. Biol., 18, 1-8, $2008 \mathrm{~b}$.

Dell'Anno, A., Mei, M. L., Pusceddu, A., and Danovaro, R.: Assessing the trophic state and eutrophication of coastal marine systems: a new approach based on the biochemical composition of sediment organic matter, Mar. Pollut. Bull., 44, 611-622, 2002.

Dell'Anno, A., Incera, M., Mei, M. L., and Pusceddu, A.: Mesoscale variability of organic matter 617 composition in NW Adriatic sediments, Chem. Ecol., 19, 33-45, 2003.

Dell'Anno, A. and Danovaro, R.: Extra-cellular DNA plays a key role in deep-sea ecosystem functioning, Science, 309(5744), 2179, doi:10.1126/science.1117475, 2005.

Deming, J. W. and Colwell, R. R.: Barophilic bacteria associated with digestive tracts of abyssal holothurians, Appl. Environ. Microbiol., 44, 1222-1230, 1982.

de Leo, F. C., Smith, R. C., Rowden, A. A., Bowden, A. B., and Clark, R. C.: Submarine-canyons: hotspots of benthic biomass and productivity in the deep-sea, Proceedings of the Royal Society B, 277, 2577-2585, 2010. 
de Stigter, H. C., Boer, W., de Jesus Mendes, P. A, Jesus, C. C., Thomsen, L., van den Bergh, G. D., and van Weering, T. C. E.: Recent sediment transport and deposition in the Nazaré Canyon, Portuguese continental margin, Mar. Geol., 246, 144-164, 2007.

Duineveld, G., Lavaleye, M., Berghuis, E., and De Wilde, P.: Activity and composition of the benthic fauna in the Whittard Canyon and the adjacent continental slope (NE Atlantic), Oceanol. Acta, 24, 69-83, 2001.

Eardly, D. C., Gallagher, J. M., and Patching, J.:Bacterial abundance and activity in deep-sea sediments from the eastern North Atlantic, Prog. Oceanogr., 50, 245-259, 2001.

Fabiano, M., Danovaro, R., and Fraschetti, S.: A three-year time series of elemental and biochemical composition of organic matter in subtidal sandy sediments of the Ligurian Sea (northwestern Mediterranean), Cont. Shelf Res., 15, 1453-1469, 1995.

Fabiano, M., Pusceddu, A., Dell'Anno, A., Armeni, M., Vanucci, S., Lampitt, R. S., Wolff, G. A., and Danovaro, R.: Fluxes of phytopigments and labile organic matter to the deep ocean in the NE Atlantic Ocean. Progr. Oceanogr. 50, 89-104, 2001.

Féral, J.-P.: Activity of the principal digestive enzymes in the detritivorous apodous holothuroid Leptosynapta galliennei and two other shallow-water holothuroids, Mar. Biol., 101, 367-379, 1989.

Ferner, M. C. and Jumars, P. A.: Responses of deposit-feeding spionid polychaetes to dissolved chemical cues, J. Exp. Mar. Biol. Ecol., 236, 89-106, 1999.

Gage, J. D. and Tyler, P. A.: Deep-Sea Biology: a Natural History of Organisms at the Deep-Sea Floor, Cambridge University Press, Cambridge, UK, 504 pp., 1991.

Gage, J. D., Lamont, P. A., and Tyler, P. A.: Deep-sea macrobenthic communities at contrasting sites off Portugal, preliminary results: 1 Introduction and diversity comparison, Int. Rev. Ges. Hydrobiol., 80, 235-250, 1995.

Gambi, C., Vanreusel, A., and Danovaro, R.: Biodiversity of nematode assemblages from deep-sea sediments of the Atacama Slope and Trench (South Pacific Ocean): Deep-Sea Res. I, 50, 103-117, 2003.

García, R. and Thomsen, L.: Bioavailable organic matter in surface sediments of the Nazaré 650 canyon and adjacent slope (Western Iberian Margin), J. Mar. Syst., 74, 44-59, 2008.

García, R., van Oevelen, D., Soetaert, K., Thomsen, L., de Stigter, H. C., and Epping, E.: Deposition rates, mixing intensity and organic content in two contrasting submarine canyons, Prog. Oceanogr., 76, 192-215, 2008.

Ginger, M. L., Billett, D. S. M., Mackenzie, K. L., Kirakoulakis, K., Neto, R. R., Boardman, D. K., Santos, V. L. C. S., Horsfall, I. M., and Wolff, G. A.: Organic matter assimilation and selective feeding by holothurians in the deep sea: some observations and comments, Prog. Oceanogr., 50, 407-421, 2001.

Howell, K., Billett, D. S. M., Tyler, P. A., and Davidson, R.: Feeding ecology of deep-sea seastars (Echinodermata: Asteroidea): a pigment biomarker approach, Mar. Ecol. Progr. Ser. 286, 103110, 2004.

Hudson, I. R., Wigham, B. D., Solan, M., and Rosenberg, R.: Feeding behaviour of deep-sea dwelling holothurian: Inferences from a laboratory investigation of shallow fjordic species, J. Mar. Syst., 57, 201-218, 2005.

Hudson, I. R., Wigham, B. D., Billett, D. S. M., and Tyler, P. A.: Seasonality and selectivity in the feeding ecology and reproduc- tive biology of deep-sea bathyal holothurians, Prog. Oceanogr., 59, 381-407, 2003

Ingels, J., Kiriakoulakis, K., Wolff, G. A., and Vanreusel, A.: Nematode diversity and its relation to the quantity and quality of sedimentary organic matter in the deep Nazaré Canyon, Western Iberian Margin, Deep-Sea Res. I, 56, 1521-1539, 2009.

Jumars, P. A.: Gourmands of mud: Diet selection in marine deposit feeders, in: Mechanisms of Diet Choice, edited by: Hughes, R. N., Blackwell Scientific Publishers, 124-156, 1993.

Jumars, P. A.: Animal guts as non-ideal chemical reactors: partial mixing and axial variation in absorption kinetics, Am. Nat., 155, 544-555, 2000.

Khripounoff, A. and Sibuet, M.: La nutrition d'echinodermes abyssaux I. Alimentation des holothuries, Mar. Biol., 60, 17-26, 1980.

Lauermann, L. M. L., Kaufmann, R. S., and Smith, K. L.: Distribution and abundance of epibenthic megafauna at a long-term time series station in the abyssal northeast Pacific, Deep-Sea Res. I, 43, 1075-1104, 1996.

Levin, L., Blair, N., DeMaster, D., Plaia, G., Fornes, W., Martins, C., and Thomas, C.: Rapid subduction of organic matter by maldanid polychaetes on the North Carolina Slope, J. Mar. Res., 55, 595-611, 1997.

Massin, C.: Effects of feeding on the environment: Holothuroidea, in: Echinoderm Nutrition, edited by: Jangoux, M. and Lawrence, J. M., Rotterdam, A.A., Balkema, 493-497, 1982.

Masson, D. G., Huvenne, V. A. I., de Stigter, H., Wolff, G. A., Kiriakoulakis, K., Arzola, R. G., and Blackbird, S.: Efficient burial of carbon in a submarine canyon, Geol., 38(9), 831-834, 2010.

Mayer, L. M., Schick, L. I., Self, R. F. L., Jumars, P. A., Findlay, R. H., Chen, Z., and Sampson, S.: Digestive environments of benthic macro-invertebrate guts: enzymes, surfactants and dissolved organic matter, J. Mar. Res., 55, 785-812, 1997.

McArdle, B. H. and Anderson, M. J.: Fitting multivariate models to community data: a comment on distance-based redundancy analysis, Ecol., 82, 290-297, 2001.

McClain, C. and Barry, J.:Habitat heterogeneity, disturbance, and productivity work in concert to regulate biodiversity in deep submarine canyons, Ecol., 91(4), 964-976, 2010.

McClintic, M. A., DeMaster, D. J., Thomas, C. J., and Smith, C. R.: Testing the FOODBANCS hypothesis: Seasonal variations in near-bottom particle flux, bioturbation intensity, and deposit feeding based on 234Th measurements. Deep-Sea Res. II, 55, 2425-2437, 2008.

Meyers, P. A.: Preservation of elemental and isotopic source identification of sedimentary organic matter, Chem. Geol., 114, 289302, 1994.

Miller, R. J., Smith, C. R., DeMaster, D. J., and Fornes, W.: Feeding selectivity and particle processing by deep-sea megafaunal deposit feeders: a ${ }^{234} \mathrm{Th}$ approach, J. Mar. Res., 58, 653-673, 2000.

Moriarty, D. J.: Feeding of Holothuria atra and Stichopus chloronotus on bacteria, organic carbon and organic nitrogen in sediments of the Great Barrier Reef, Aust. J. Mar. and Freshw. Res., 33, 255-263, 1982.

Oliveira, A., Santos, A. I., Rodrigues, A., and Vitorino, J.: Sedimentary particle distribution and dynamics on the Nazaré Canyon system and adjacent shelf (Portugal), Mar. Geol., 246, 105-122, 2007. 
Palanques, A., Garcia-Ladona, E., Gomis, D., Martin, J., Marcos, M., Pascual, A., Puig, P., Gili, J. M., Emelianov, M., Monserrat, S., Guillen, J., Tintore, J., Segura, M., Jordi, A., Ruiz, S., Basterretxea, G., Font, J., Blasco, D., and Pages, F.: General patterns of circulation, sediment fluxes and ecology of the Palamo (La Fonera) submarine canyon, northwestern Mediterranean, Prog. Oceanogr., 66, 89-119, 2005.

Pawson, D., Vance, D. J., and Ahearn, C.: Western Atlantic sea cucumbers of the Order Molpadiida (Echinodermata: Holothuroidea), Bull. Biol. Soc. Washington, 10, 311-327, 2001.

Penry, D. L. and Jumars, P. A.: Gut architecture, digestive constraints and feeding ecology of deposit-feeding and carnivorous polychaetes, Oecologia, 82, 1-11, 1990.

Penry, D. L. and Jumars, P. A.: Chemical reactor analysis and optimal digestion, Bioscience, 36, 310-315, 1986.

Penry, D. L. and Jumars, P. A.:Modelling animals guts as chemical reactors, American Naturalist, 129, 69-96, 1987.

Pfannkuche, O. and Thiel, H.: Meiobenthic stocks and benthic activity on the northeast Svalbard Shelf and in the Nansen Basin, Polar Biol., 7, 253-266, 1987.

Purinton, B. L., DeMaster, D. J., Smith, C. R., and Thomas, C. J.: ${ }^{14} \mathrm{C}$ as a tracer of labile organic matter in Antarctic benthic foodwebs, Deep-Sea Res. II, 55, 2438-2450, 2008.

Pusceddu, A., Dell'Anno, A., Fabiano, M., and Danovaro, R.: Quantity and bioavailability of sediment organic matter as signatures of benthic trophic status, Mar. Ecol. Prog. Ser., 375, 41-52, 2009

Pusceddu, A., Bianchelli, S., Canals, M., Sanchez-Vidal, A., Durrieu De Madron, X., Heussner, S., Lykousis, V., de Stigter, H., Trincardi, F., and Danovaro, R.: Organic matter in sediments of canyons and open slopes of the Portuguese, Catalan, Southern Adriatic and Cretan Sea margins, Deep-Sea Res. Part I, 57, 441457, 2010

Quaresma, L. S., Vitorino, J., Oliveira, A., and Silva, J.: Evidence of sediment resuspension by nonlinear internal waves on the western Portuguese mid-shelf, Mar. Geol, 246, 123-143, 2007.

Rhoads, D. C. and Young, D. K.: Animal-sediment relations in Cape Cod Bay, Massachusetts II. Reworking by Molpadia oolitica (Holothuroidea), Mar. Biol., 11, 255-261, 1971.

Roberts, D., Billett, D. S. M., McCartney, G., and Hayes, G. E.: Prokaryotes on the tentacles of deep-sea holothurians - a novel form of dietary supplementation, Limnol. Oceanogr., 36, 14471452, 1991.

Roberts, D., Moore, H. M., Manship, B., Wolff, G. A., Santos, V. L. C., Horsfall, I. M., Patching, J., and Eardly, D.: Feeding Strategies and Impact of Holothurians in the Deep-sea, in: Irish Marine Science 1995, edited by: Keegan, R. B. F. A. O., Galway University Press, 237-252, 1996.

Roberts, D., Gebruk, A. V., Levin, V., and Manship, B. A. D.: Feeding and digestive strategies in deposit-feeding holothurians, Oceanogr. Mar. Biol. Annu. Rev., 38, 257-310, 2000.

Roberts, D., Moore, H. M., Berges, J., Patching, J. W., Carton, M. W., and Eardly, D. F.: Sediment distribution, hydrolytic enzyme profiles and bacterial activities in the guts of Oneirophanta mutabilis, Psychropotes longicauda and Pseudostichopus villosus: what do they tell us about digestive strategies of abyssal holothurians?, Prog. Oceanogr., 50, 443-458, 2001.

Rowe, G. T., Polloni, P. T., and Haedrich, R. L.: The deep-sea macrobenthos on the continental-margin of the Northwest Atlantic-
Ocean, Deep-Sea Res. I, 29, 257-278, 1982.

Ruhl, H. A. and Smith, K. L.: Shifts in deep-sea community structure linked to climate and food supply, Science, 305, 513-515, 2004.

Ruhl, H. A.: Abundance and size distribution dynamics of abyssal epibenthic megafauna in the northeast Pacific, Ecol., 88, 12501262, 2007.

Ruhl, H. A., Ellena, J. A., and Smith Jr., K. L.: Connections between climate, food limitation, and carbon cycling in abyssal sediment communities: a long time-series perspective, P. Natl. Acad. Sci. USA, 105, 17006-17011, 2008.

Schmidt, S., de Stigter, H. C., and van Weering, T. C. E.: Enhanced short-term sediment deposition within the Nazaré Canyon, North-East Atlantic, Mar. Geol., 173, 55-67, 2001.

Searle, S. R., Casella, G., McCulloch, C. E. (eds.): Variance components, John Wiley and Sons, New York, New York, USA, 1992.

Sibuet, M., Khripounoff, A., Deming, J., Colwell, R., and Dinet, A.: Modification of the gut contents in the digestive tract of abyssal holothurians, in: Proceedings of the International Echinoderm Conference, edited by: Lawrence, J. M., Balkema, Rotterdam, Tampa Bay, 421-428, 1982.

Sibuet, M.: Deposit-feeding invertebrates in the deepsea ecosystem. Selectivity in feeding and diet of holothurians, Oceanis, 10, 623876, 1984.

Sibuet, M.: Quantitative distribution of echinoderms (Holothuroidea, Asteroidea, Ophiouroidea, Echinoidea) in relation to organic matter in the sediment, in deep sea basins of the Atlantic Ocean, in: Echinodermata. Proceedings of the Fifth International Echinoderm Conference, edited by: Keegan, B. F. and O'Connor, B. D. S., Balkema, Rotterdam, Galway 24-29 September 1984, Galway, Ireland, 99-108, 1985.

Smallwood, B. J., Bett, B. J., Smith, C. R., Gage, J. D., Patience, A., Hoover, D., and Wolff, G. A.: Megafauna can control the quality of organic matter in marine sediments, Naturwissenschaften, 86(7), 320-324, 1999.

Smith Jr., K. L., Kaufman, R. S., and Wakefield, W. W.: Mobile megafaunal activity monitored with a time-lapse camera in the abyssal North Pacific, Deep-Sea Res. I, 40, 2307-2324, 1993.

Smith Jr., K. L., Baldwin, R. J., and Ruhl, H. A.: Climate effect on food supply to depths greater than 4000 meters in the northeast Pacific, Limnol. Oceanog., 51, 166-176, 2006.

Smith, C. R., de Leo, F. C., Bernadino, A. F., Sweetman, A. K., and Martinez, P. A.: Abyssal food limitation, ecosystem structure and climate change, Trends in Ecology and Evolution, 23(9), 518528, 2008.

Soetaert, K., Heip, C., and Vincx, M.: The meiobenthos along a Mediterranean deep-sea transect off Calvi (Corsica) and in an adjacent canyon, Mar. Ecol., 12, 227-242, 1991.

Tselepides, A., Polychronaki, T., Marrale, D., Akoumianaki, I., Dell'Anno, A., Pusceddu, A., and Danovaro, R.: Organic matter composition of the continental shelf and bathyal sediments of the Cretan Sea (NE Mediterranean), Prog. Oceanogr., 46, 311-344, 2000.

Turley, C. M. and Mackie, P. J.: Bacterial and cyanobacterial flux to the deep NE Atlantic on sedimenting particles, Deep-Sea Res. I, 42, 1453-1474, 1995.

Tyler, P., Amaro, T., Arzola, R., Cunha, M. R., de Stigter, H., Gooday, A., Huvenne, V., Ingels, J., Kiriakoulakis, K., Lastras, G., Masson, D., Oliveira, A., Pattenden, A., Vanreusel, A., 
Van Weering, T., Vitorino, J., Witte, U., and Wolff, G.: Europe's Grand Canyon: Nazaré Submarine Canyon, Oceanography, 22(1), 46-57, 2009.

Vetter, E. W. and Dayton, P. K.: Macrofaunal communities within and adjacent to a detritus-rich submarine canyon system, DeepSea Res. II, 45, 25-54, 1998.

Vetter, E. W. and Dayton, P. K.: Organic enrichment by macrophyte detritus, and abundance patterns of megafaunal populations in submarine canyons, Mar. Ecol. Prog. Ser., 186, 137-148, 1999.

Vetter, E. W., Smith, C. R., and de Leo, F. C.: Hawaiian hotspots: enhanced megafaunal abundance and diversity in submarine canyons on the oceanic islands of Hawaii, Mar. Ecol., 31, 183$199,2010$.

Vitorino, J., Oliveira, A., Jouanneau, J.-M., and Drago, T.: Winter dynamics on the northern Portuguese shelf. Part 2: bottom boundary layers and sediment dispersal, Prog. Oceanogr., 52, 155-170, 2002a.

Vitorino, J., Oliveira, A., Jouanneau, J. M., and Drago, T.: Winter dynamics on the northern Portuguese shelf Part 1: physical processes, Prog. Oceanogr., 52, 129-153, 2002 b.
Wakeham, S. G., Hedges, J. I., Lee, C., Peterson, M. L., and Hernes, P. J.: Compositions and transport of lipid biomarkers through the water column and surficial sediments of the equatorial Pacific Ocean, Deep-Sea Res. II, 44, 2131-2162, 1997.

Wigham, B. D., Hudson, I. R., Billett, D. S. M., and Wolff, G. A.: Is long-term change in abyssal Northeast Atlantic driven by qualitative changes in export flux? Evidence from selective feeding in deep-sea holothurians, Prog.Oceanogr., 59, 409-441, 2003.

Witbaard, R., Duineveld, G. C. A., Kok, A., van der Weele, J., and Berghuis, E. M.: The response of Oneirophanta mutabilis (Holothuroidea) to the seasonal deposition of phytopigments at the Porcupine Abyssal Plain in the Northeast Atlantic, Prog. Oceanogr., 50, 423-441, 2001.

Witte, U., Wenzhöfer, F., Sommer, S., Boetius, A., Heinz, P., Aberle, N., Sand, M., Cremer, A., Abraham, W.-R., Jørgensen, B. B., and Pfannkuche, O.: In situ experimental evidence of the fate of a phytodetritus pulse at the abyssal sea floor, Nature, 424, 763-766, 2003. 